\title{
I N HALTSVERZEICHN IS
}

A. Vorbemerkungen

Zum Stand der Forschung über Jahwes Königtum . . . . . . . . . . . 1

B. Die Königsgötter im Baalmythos . . . . . . . . . . . . . . . . . . . 4

1. Name und Wesen Els und Baals. . . . . . . . . . . . . . . . 4

2. Der Baalmythos . . . . . . . . . . . . . . . . . . 9

C. Das Königtum der Götter in Ugarit

(Aussagen über das Gottkönigtum in den RS-Texten im Vergleich mit dem

Alten Testament) . . . . . . . . . . . . . . . . . . . . 17

1. Das Königtum Els . . . . . . . . . . . . . . . . . . . . . . 18

2. Das Königtum Baals . . . . . . . . . . . . . . . . . . . 21

a) Allgemeine Kennzeichen . . . . . . . . . . . . . . . . . . 21

b) Der Gottesberg im Norden . . . . . . . . . . . . . . . . 23

c) Das Richtertum . . . . . . . . . . . . . . . . . . . . . 27

Exkurs: Psalm 82 ...................... 32

d) Der Kampf gegen die Feinde . . . . . . . . . . . . . . . . . 35

e) Das Königtum in Ewigkeit . . . . . . . . . . . . . . . . . 43

f) Psalm 29 . . . . . . . . . . . . . . . . . . . . . . 46

Exkurs: El und Baal als Schöpfer . . . . . . . . . . . . . 49

3. Das Verhältnis von Els zu Baals Königtum . . . . . . . . . . . . . 52

4. Die Bedeutung von $m l k$ »König* . . . . . . . . . . . . . . . . 54

5. Königtum und Tempel . . . . . . . . . . . . . . . . . 56

Anhang: Der Baalmythos im Kult . . . . . . . . . . . . . . 59

D. Das Königtum Gottes in Israel . . . . . . . . . . . . . . . . . . . 64

1. Erwähnungen von Jahwes Königtum aus der Zeit vor der Landnahme. . 64

2. Jahwe als König der Götter . . . . . . . . . . . . . . . . . . . 69

3. Das neue Verständnis von $m l k$. . . . . . . . . . . . . . . . . . . 72

4. Jerusalem oder Silo? . . . . . . . . . . . . . . . . . . . 76

Literaturverzeichnis . . . . . . . . . . . . . . . . . . 80

Register . . . . . . . . . . . . . . . . . . . 89 
